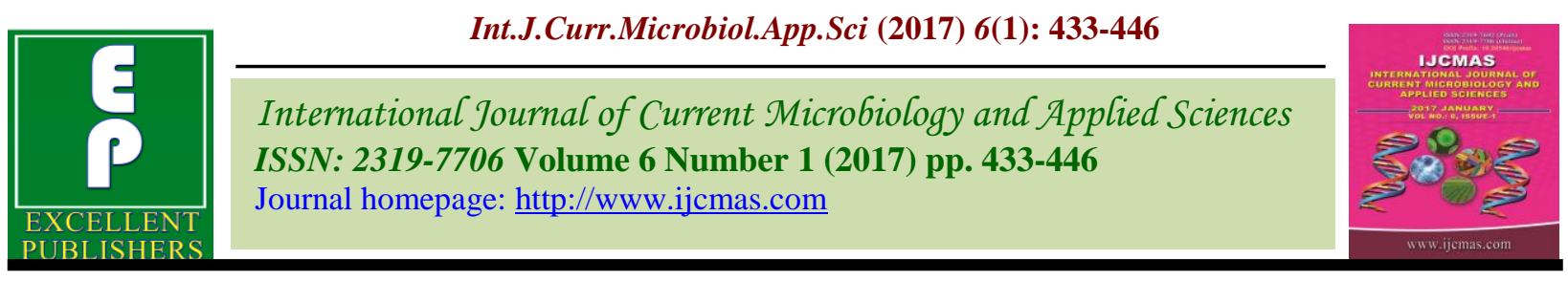

Original Research Article

http://dx.doi.org/10.20546/ijcmas.2017.601.052

\title{
In vitro Antimicrobial Activity of Some Commercial Toothpastes
}

\author{
Gerald Ngo Teke $^{1 *}$, Ngolle Godwill Enongene ${ }^{2}$ and Akah Roland Tiagha ${ }^{2}$ \\ ${ }^{1}$ Department of Biomedical Sciences, Faculty of Health Sciences, University of Bamenda- \\ Cameroon, P.O.Box 39, Bambili \\ ${ }^{2}$ Department of Medical Laboratory Sciences, Faculty of Health Sciences, University of \\ Bamenda-Cameroon, P.O. Box 39, Bambili \\ *Corresponding author
}

\section{A B S T R A C T}

\section{Keywords \\ Oral pathogens, antimicrobial activity, inhibition zone, toothpastes, ingredients.}

\section{Article Info}

Accepted:

18 December 2016 Available Online: 10 January 2017

\begin{abstract}
Despite great improvements in global oral health status, dental caries still remain one of the most prevalent diseases. Yet some brands of toothpastes claim to be effective antimicrobial agents. This study was therefore designed to evaluate the in vitro antimicrobial activity of commercially available toothpastes against some microorganisms involved in tooth infections. Agar disc diffusion method was used to test the antimicrobial activity of ten different toothpastes at various concentrations (1:2;1:4 and 1:8 dilutions) against Porphyromonas gingivalis, Escherichia coli, Staphylococcus aureus and Candida albicans. The sensitivity of tested toothpastes towards each microorganism was expressed as a percentage of the mean clear zone diameter. Statistical analysis was performed with the help of Statistical Package for Social Sciences (SPSS) version 19 with significance considered at $p<0.05$ using Student Newman Keuls. All the tested toothpastes inhibited the growth of $P$. gingivalis at various levels: Signal (67.3\%), Colgate Protection Max (63.6\%) and Colgate Herbal (62.7\%). Test concentration of 1:2 dilution of these toothpastes was most effective on $E$. coli with clear zones ranging from $11.7 \mathrm{~mm}$ (Oral B) to $23.3 \mathrm{~mm}$ (Aloe vera). Generally the inhibition of $S$. aureus growth by these dentifrices even at higher test concentrations was weak, with clear zones ranging from 8.3 to $15.0 \mathrm{~mm}$. No growth inhibitory activity was observed for Mericle (least effective in bacterial growth inhibition) against $C$. albicans at all the tested concentrations. Dentix (25.8\%), Airsun $(30.7 \%)$, Special 2 plus $(22.2 \%)$ and Oral B $(22.7 \%)$ were equally less sensitive to this microorganism compared to the controls. Our in vitro study has shown antimicrobial activities of the mentioned toothpastes against $P$. gingivalis, E. coli, S. aureus and $C$. albicans. Thus they can be used to control dental infections.
\end{abstract}

\section{Introduction}

The mouth is continually being bombarded by the various rudiments of nature and when coupled with a perpetual warm and moist climate, serves as a hot bed for the resident and development of numerous microbial populations (Oranusi and Akhigbe, 2013). Pathogenic and nonpathogenic bacteria are constant residents of the human mouth. Dental caries, also known as tooth decay or a cavity, is an infection, generally bacterial in origin, localized and transmissible, that results in the destruction of hard dental tissue. It is one of the most common chronic infectious diseases in the world (Inetianbor et al., 2014, Yoo et al., 2007). 
Many microorganisms have been reported to be involved in the causation of dental caries through the metabolism of bacteria in plaque attached to the surface of the tooth (Alsaimary, 2008). S. aureus and $S$. epidermidis are major human pathogens, responsible for a number of hospital acquired infections known initially to colonize several locations in the human body, but the mouth and hands are the main reservoirs for propagation of this pathogen in the hospital environment (Lowy, 1998; Piochi and Zelante, 1974). Streptococcus mutans is one of the main opportunistic pathogens of dental caries which plays a central role in fermenting carbohydrates, resulting in acid production and leading to the demineralization of the tooth enamel (Robert et al., 2011; Diane et al., 2006). In addition, other microfloras like Escherichia coli and Candida albicans are also associated with active caries lesions (Manupati, 2011). The early stage of dental caries is characterized by a destruction of superficial dental structures caused by acids which are by products of carbohydrates metabolism by bacteria (Loesche, 1986). Colonization of teeth by cariogenic bacteria is one of the most important risk factors in the development of dental diseases (Agbelusi et al., 2007). Candida albicans is the common cause of oral thrush, endocarditis, septicemia, vaginitis and infection of skin, nails and lungs and it is by far the fungal specie most commonly isolated from infected root canals (Oztan et al., 2006). Porphyromonas gingivalis is a periodontal pathogen known for toothdecay activity (How et al., 2016). The binding capacity of microbes is a key feature to their virulence (Krzysciak et al., 2014).

The adherence of microorganisms within the plaque biofilm to cause dental caries could be prevented by proper use of dentifrices and toothbrushes. Toothpastes and toothbrushes are the two products commonly used to reduce microbial population in the mouth The American Dental Association defines a toothpaste or dentifrice as a paste used with the aid of a toothbrush to cleanse and maintain the aesthetic and wellbeing of the oral buccal cavity (Nwankwo and Ihesiulo, 2014). It should be noted that the bathroom can easily contaminate toothbrushes with other microbial species (Otoikhian and Okoror, 2012).

Minor tooth destruction could be easily managed to restore proper tooth aesthetics and other functions than trying in vain to regenerate considerable portions of the tooth structure. In this regard, dental health organizations say no to dental caries by advocating preventive and prophylactic measures, through regular oral hygiene and dietary modifications (Inetianbor et al., 2014).

According to Okpalugo et al. (2009), toothpastes is classified as drugs not cosmetics, because drugs contain an active ingredient which act against microorganisms, such as Triclosan 2, 4, 4' trichloro-2'hydroxydiphenyl ether which is a broadspectrum agent against Gram-positive and Gram-negative bacteria, viruses and yeasts (Andiara et al., 2014; Prasanth et al., 2011), and fluoride, to effectively reduce mouth bacteria and contribute to dental health. Many studies have reported the use of triclosan as a good an antiplaque agent (Gunsolley, 2006; Kjaerheim V, Waaler, 1994, Davies et al., 2004). Moreover Triclosan promotes inhibition of cyclooxygenase/lipoxygenase pathways and exhibits anti-inflammatory effects (Andiara et al., 2014; Davies et al., 2010). Other active agents such as surfactants, antibacterial agents, baking soda, peroxide, metal sacks herbal and natural extracts and chloride dioxide (William and Cummins, 2003) could be incorporated into the treatment plan. Nowadays, the maintenance of good oral hygiene is the key to the prevention 
of dental diseases and the formation of plaque on the tooth surface which is characterized by the progression from a limited number of pioneer microbial species to the complex flora of mature dental plaque (Alsaimary, 2008). This progression involves initial adherence of bacteria to the saliva pellicle and subsequent accumulation by growth and interbacterial adherences to the hard enamel tissue (Kallahalli et al., 2015). Halitosis, also called bad breath is due to the activities of oral micro flora (Jeronimo et al., 2013), thus antimicrobial agents need to be added in toothpastes.

When these substances are added to oral products, they kill microorganisms by disrupting their cell walls and inhibiting their enzymatic activity (Shetty, 2007). One of the most promising possibilities for the control of tooth decay involves the use of combined topical applications of fluoride with chemotherapeutic agents to increase the resistance of newly erupted teeth, enhance demineralization of hypomineralized enamel, and reduce microorganisms from infected teeth (Ihsan, 2008). Agents with demonstrable in vitro and in vivo activity may have a reduced antimicrobial effect when formulated into dentifrice (Violet et al., 2012).

According to Nwakanma (2014) and Teke et al. (2011), antimicrobial agents usually will kill (microbicidal) or inhibit (microstatic) the growth of microorganisms. Despite great improvements in the global oral health status, dental caries still remain one of the most prevalent diseases (Inetianbor et al., 2014). Some brands of toothpastes claim to be effective antimicrobial agents and best for oral hygiene, but how effective they are is the question since the prevalence of tooth cavies is still a public concern. This study was therefore designed to evaluate the antimicrobial activity of commercially available toothpastes against some microorganisms involved in tooth infections.

\section{Material and Methods}

\section{Collection of samples and test organisms}

Ten different brands of toothpastes were bought from different merchants shops in the town of Bamenda. These toothpastes included: Extra Fresh Angola, Airsun, Mericle, Oral-B, Dentix, Aloe vera good week, Colgate Herbal, Colgate Maximum cavity protection, Signal, Special 2 plus. The composition, active ingredients and manufacturers of these dentifrices are given in Table 1. These toothpastes were taken to the Microbiology/ Bacteriology Laboratory of the Yaounde University Hospital Teaching Center (UHTC) for analysis. The dental microorganisms used in this study constituted pure colonies of Candida albicans (ATCC10231), Escherichia coli (ATCC25922), Staphylococcus aureus (ATCC25923, resistant) and a non-typed colony of Porphyromonas gingivalis which were obtained from the Microbiology/ Bacteriology laboratory of the Yaounde University Teaching Hospital Center, Cameroon.

Identification, growth activation and maintenance of test microorganisms

The microorganisms collected were checked for identity and purity using standard biochemical and staining methods (Aneja, 2003; Cappuccino and Sherman, 1995). These microorganisms were later subcultured as follows; with a sterile wire loop the colonies were streaked on their various media. Escherichia coli was streaked on Hektoen enteric agar, Porphyromonas gingivalis on Chocolate blood agar, Staphylococcus aureus on mannitol salt agar and Candida albicans on Sabouraud plus Chloramphenicol. The Streaked plates were then incubated aerobically in a "Memmert'" incubator for 24 hours at $37^{\circ} \mathrm{C}$. Chocolate agar was incubated 
anaerobically in a candle jar. Microbial cultures were stored and maintained in nutrient broth/agar accordingly at $4^{\circ} \mathrm{C}$ to be used later.

\section{Preparation of dentifrices}

A solution of each of the ten dentifrices was made by dissolving 1 gram of each of the toothpastes in $1 \mathrm{ml}$ of sterile distilled water. Further dilutions in distilled water were made to obtain concentration ratios of 1:2, 1:4 and $1: 8$.

\section{Antimicrobial assay}

The agar disc diffusion technique was used to test different dentifrices for antimicrobial activities whence the diameter of growth inhibition zones were determined (Teke et al., 2013; Chattopadhyay et al., 2001). Briefly, Two to three identical colonies were taken from each of the four microbes under study showing significant growth with a sterile wire loop and emulsified in sterile saline distilled water. This new microbe suspension was adjusted to $0.5 \mathrm{Mc}$ Farland standard (about $1.5 \times 10^{7} \mathrm{cfu} / \mathrm{ml}$ of bacteria and $1.5 \times 10^{6}$ spores/ml for yeast) before streaking about 20 $\mu l$ onto the Muller Hinton agar/Sabouraud dextrose agar accordingly with the aid of sterile swabs. The plates were allowed for microbial seeding for about 1 hour. Filter paper discs (Whattmann $n^{\circ} 3$ ) of diameter 6 mm were prepared and soaked with $10 \mu \mathrm{l}$ of each of the different toothpastes dilutions (1:2, 1:4 and 1:8) and placed onto the seeded MHA/SDA. Controls were made of distilled water (negative); Levofloxacine and cotrimoxazole (positive for bacteria); and Miconazole and ketoconazole (positive for yeast). All tests were performed in triplicate and the mean zones of inhibitions calculated $(n=3)$.

The microorganism was considered susceptible/resistant to a particular dentifrice when diameter $>7 \mathrm{~mm}$ or $<7 \mathrm{~mm}$ was observed respectively.

The sensitivity of the tested toothpastes towards each microorganism was expressed as a percentage of the mean zone diameter produced by the toothpaste (Dt) to that of the mean zone diameter produced by the reference substances (Dr). i.e.: Sensitivity is equal to $100 \mathrm{x} \mathrm{Dt} / \mathrm{Dr}$.

\section{Clearance}

Administrative authorization to conduct this prospective study was obtained from the Director of the Yaounde University Teaching Hospital Center, Cameroon.

\section{Statistical analysis}

Statistical analysis was performed with the help of Statistical Package for Social Sciences (SPSS) version 19. Level of statistical significance was considered at $p<0.05$ with Student Newman Keuls.

\section{Results and Discussion}

\section{Antimicrobial activity against Porphyromonas gingivalis}

All the tested toothpastes inhibited the growth of $P$. gingivalis at various levels. This bacterium was highly susceptible to three of the toothpastes: Signal (67.3\%), Colgate Protection Max (63.6\%) and Colgate Herbal (62.7\%) with inhibition zones ranging from $9.7 \mathrm{~mm}$ to $19 \mathrm{~mm}$ (Table 2).

Mericle (25.6\%) and Extra fresh Angola $(23.8 \%)$ were the least effective in their bacterial growth inhibitory actions. They were not active $(0 \mathrm{~mm})$ at the test concentration (1:8 dilution). Generally the mean diameters of the growth inhibitory zones for the tested concentrations were significantly $(p<0.05)$ different. It was also observed that zone of 
inhibition decreased with increase in dilution (i.e. decrease in concentration).

\section{Antimicrobial activity against Escherichia coli}

The highest tested concentration (1:2 dilution) of these toothpastes most effective in inhibiting the growth of $E$. coli with clear zones ranging from $11.7 \mathrm{~mm}$ (Oral B) to 23.3 $\mathrm{mm}$ (Aloe vera good week). A weak antibacterial activity was observed at a concentration of 1:8 dilution for a majority of the toothpastes with the rest non-active (Table 3). Mericle was the lone toothpaste showing the least sensitivity to E. coli $(30.5 \%)$. The sensitivity of the studied toothpastes towards $E$. coli with respect to the average zone diameter from the reference substances ranges from Aloe vera $(79.1 \%)$, Colgate Herbal (74.5\%), Colgate protection Max (65), Signal (62.3\%), Extra fresh Angola (45.9\%) and Dentix $(44.1 \%)$ in decreasing order for all values greater than $40 \%$.

\section{Antimicrobial activity against Staphylococcus aureus}

Generally the inhibition of $S$. aureus growth by these toothpastes even at higher test concentrations was weak, with clear zones ranging from 8.3 to $15.0 \mathrm{~mm}$ Table 4 . The mean diameter of clear zones produced by the most sensitive dentifrices [Dentix $(11.0 \mathrm{~mm})$, Colgate Protection Max $(10.9 \mathrm{~mm})$ and Colgate Herbal $(10.2 \mathrm{~mm})]$ were comparable at $p<0.05$ though at the same time significantly lower than those of the reference substances. S. aureus showed some degree of resistance to Signal (27.5\%), Airsun (28.0\%) and Mericle (24.2\%).

\section{Antimicrobial activity against Candida albicans}

No growth inhibitory activity was observed for Mericle against $C$. albicans at all the tested concentrations (Table 5). Dentix (25.8\%), Airsun (30.7\%), Special 2 plus $(22.2 \%)$ and Oral B (22.7\%) were less sensitive to this microorganism. The average zone diameters for all the tested toothpastes were significantly $(p<0.05)$ lower than those from the reference substances. Antifungal activities of these dentifrices were concentration dependent.

The main aim of this study was to evaluate the antimicrobial activity of commercially available toothpastes in Bamenda, Cameroon against some microorganisms involved in buccal infections. The microorganisms used in this study were chosen on the basis that they are involved in tooth decay (Socransky and Haffajee, 2005). The degree of infection caused by these microorganisms can range from mere inflammation of the gingival to complete tooth destruction. Bacteria in biofilms (variety of bacteria embedded in a polysaccharide matrix) just as plaques are known to be less sensitive to antimicrobial agents. However, the sensitivity of dentifrices is increased upon plaque removal (using a brush) as shown by Jenner et al. (2013). Persistent dental plaque is at high risk for the development of dental and periodontal diseases (Mogammad et al., 2011).

One of the most commonly used anti-plaque chemical agents is chlorhexidine digluconate. Even though this agent has well documented antimicrobial efficacy against bacteria associated with dental plaque, it requires multiple applications in order to be clinically effective (Mogammad et al., 2011; Addy and Moran, 2008). Though the toothpastes used in this study did not contain chlorhexidine, their antimicrobial activities indicate that many other ingredients found in them possess antimicrobial potentials.

Triclosan is the best among the many chemical agents incorporated in toothpastes known to exhibit antimicrobial activities. This 
is followed by sodium floride and sylodent respectively. The latter two agents (ingredients) were reported to greatly inhibit the growth of $E$. coli. Also, Sylodent is known to clean, eliminate stains from teeth (Kallahalli et al., 2015). In this study, Airsun was the lone toothpaste containing triclosan and floride salts though its activity was however average. The others like Signal, Colgate Herbal, Colgate protection max, Aloe vera good week and Dentix with relatively high antimicrobial activities probable contain these active ingredients in greater amounts. Colgate dentifrice has been reported to active against the growth of microorganisms (Williams et al., 2005). The effectiveness of fluoride toothpaste is concentration dependent (Fejerskov and Kik, 2003) just like that of any other active ingredient.

Fluorides are abundantly used in many oral health products including toothpastes and mouth rinses as they help in caries prevention by reducing dental caries between 30 and $70 \%$ compared with no floride therapy (Kallahalli et al., 2015). Hydrated silica, sodium floride and amine floride were ingredients in most of the tested toothpastes that have shown antimicrobial activities against (Farogh et al., 2014).

Netuschil et al. (2005) showed that a fluoridefree herbal based toothpaste that contains peppermint, clove, chamomomile, mastic gum, propalis wax and chlorophyll, was more effective in the management of gingivitis. Aloe vera good week toothpaste used in this work contained peppermint and chlorophyll among others. Its activity may have been improved by these components.

Other proposed active ingredients include myrrh, sage, eucalyptus, tea tree oil, mallow, matricariae, eugenol and propolis for herbal toothpastes have documented antibacterial activity (Didry et al., 1994). Some of these ingredients were found in Colgate Herbal (eugenol and tea tree oil) used in this study. This dentifrice was among the most active against microbial growth. It should be noted other toothpastes like Dentix, Oral-B, Extra Fresh Angola, Signal and Mericle equally contain various ingredients that could work in synergy to improve on their antimicrobial activities.

In the present study, the antimicrobial activities of the studied toothpastes varied for one microorganism and across the different microorganisms. Some researchers who did a similar study reported that less than $50 \%$ of available toothpastes had antibacterial activities and antiplaque potentials (Ozaki et al., 2006). This could be understood since there are different manufacturers producing toothpastes with varied composition and levels of ingredients.

Furthermore, they may not respect strictly the composition as indicated on their products. Hence the disparities observed in the antimicrobial activities of the various dentifrices.

Though our in vitro study reports that the tested toothpastes have antimicrobial properties, it should be understood that the oral cavity, being a more complex milieu, may exert a significant influence on the clinical outcome of these toothpastes.

In conclusion, the various brands of toothpaste (Colgate Herbal, Extra Fresh Angola, Colgate Maximum protection, Airsun, Oral-B, Dentix, Aloe vera Good Week, Mericle, Signal and Special 2 plus) used in our in vitro study have shown antimicrobial activities comparable to broad spectrum antimicrobials against some dental microorganisms ( $P$. gingivalis, E. coli, $S$. aureus and $C$. albicans). These toothpastes can be used to control dental infections. 
Table.1 Various Toothpastes evaluated in the study, their compositions and manufacturers

\begin{tabular}{|c|c|}
\hline $\begin{array}{c}\text { Toothpaste } \\
\text { brand }\end{array}$ & Composition as listed on package \\
\hline $\begin{array}{l}\text { Extra Fresh } \\
\text { Angola }\end{array}$ & $\begin{array}{l}\text { Calcium Carrageenan, Cellulose Gum, D\&C Yellow No. } 10 \text { Lade, FD\&C Blue No. } 1 \text { Lake, flavor, Glycerin, Hydrated Silica, PEG-8, } \\
\text { Sodium Benzoate, Sodium Bicarbonate, Sodium Lauryl Sulfate, Sodium Saccharin, Sorbitol, Titanium Dioxide, Water. }\end{array}$ \\
\hline Airsun & $\begin{array}{l}\text { Aqua, Sorbitol, Hydrated Silica, Calcium Carbonate, Glycerin, PEG-12, Sodium Lauryl Sulfate, Sodium Monofluorophosphate, } \\
\text { Flavour, Cellulose Gum, Sodium Silicate, Sodium Saccharin, Carrageenan (Chondrus Crispus), Xanthan Gum, Sodium Bicarbonate, } \\
\text { Mehtyparaben, Butylparaben, Ethylparaben, Propylparaben, Isobutylparaben, Triclosan, CI 19140, CI 42090. }\end{array}$ \\
\hline Mericle & $\begin{array}{l}\text { Sorbitol, Silica, Water, Sodium Lauryl Sulfate, Sodium Carboxymethyl cellulose, Flavors, CI 73015, CI 19140, Sodium Saccharin, } \\
\text { Pearl Powder. }\end{array}$ \\
\hline Oral-B & $\begin{array}{l}\text { Sorbitol, Aqua, Hydrated Silica, Sodium Lauryl Sulfate, Aroma, Cellulose Gum, Trisodium phosphate, Sodium Phosphate, Sodium } \\
\text { Saccharin, Sodium Fluoride, Carbomer, limonene, CI 19140, Eugenol, CI } 42090 .\end{array}$ \\
\hline Dentix & $\begin{array}{l}\text { Water, Calcium carbonate, Hydrated Silica, Sorbitol, Glycerin, Sodium Lauryl Sulfate, Tetrapottasium Pyrophoshate, Disodium } \\
\text { Pyrophosphate, Tetrasodium Pyrophosphate, Aroma, Cellulose Gum, Limonene, sodium Fluoride, Sodium Saccharin, Xanthan Gum. }\end{array}$ \\
\hline $\begin{array}{l}\text { Aloe vera } \\
\text { good } \\
\text { week }\end{array}$ & $\begin{array}{l}\text { Glycerin (Vegetable Source), Sorbitol (Plant origin) Hydrated Silica(Mineral origin), Aloe Barbadensis, Aqua, Sodium Lauryl } \\
\text { Sarcosinate (Protein Derivative), Carboxy-methyl Chitosan (Marine Origin), Mentha piperita (peppermint oil), Escin (Horse Chesnut, } \\
\text { Hydroxyethylcellulose(Plant origin), Menthol (Natural origin), Ubiquin one (Co-Enzyme Q10), Melaleuca Alternifolia(Tea tree oil), } \\
\text { Sodium Hydroxy- mrthylglycinate (protein origin), Xylitol(Plant origin), Citric Acid, C175810(Chlorophyl-Natural colouring). }\end{array}$ \\
\hline $\begin{array}{l}\text { Colgate } \\
\text { Herbal }\end{array}$ & $\begin{array}{l}\text { Calcium Carbonate, Water, Sorbitol, hydrated Silica, Sodium Laury Sulfate, Sodium Monofluorophosphate, Flavor, Cellulose gum, } \\
\text { Magnesium Aluminium Silicate, Sodium Saccharin, Sodium Carbonate, Benzyl Alcohol, Sodium bicarbonate, Eucalyptus Globulus } \\
\text { Leaf oil, Commiphora Myrrha Extract, Chamomilla Recutita (Matricaria) Flower Extract, Melaleuca Alternifolia (Tea tree) Leaf oil, } \\
\text { Salvia officinalis(sage) oil, Eugenol, Limonene, CI } 74260 .\end{array}$ \\
\hline Colgate & Sodium monofluorophosphate, Aroma, Cellulose Gum, Sodium Carbonate, Tetrasodium Pyrophosphate, benzyl Alcohol, Sodium \\
\hline $\begin{array}{l}\text { Maximum } \\
\text { Protection }\end{array}$ & Saccharin, Sodium Hydroxide, Limonene. \\
\hline SIGNAL & $\begin{array}{l}\text { Calcium Glycerophosphate, Calcium Carbonate, Aqua, Sorbitol, Hydrated Silica, Sodium Lauryl, Sulfate, Sodium } \\
\text { Monofluorophosphate, Aroma, Cellulose Gum, Potassium Citrate, Trisodium, Phosphate, Sodium Saccharin, Calcium, } \\
\text { Glycerophosphate, Phenyl Carbinol, Glycerin, Limoneme, CI } 12490 .\end{array}$ \\
\hline Special 2 plus & $\begin{array}{l}\text { Calcium carbonate, Sorbitol, Water, Silica, Sodium Lauryl Sulphate, Flavour, Sodium Carboxy Methyl Cellulose, Sodium cilicate, } \\
\text { Sodium, Benzoite, Sodium Saccharin. }\end{array}$ \\
\hline
\end{tabular}


Table.2 P. gingivalis susceptibility to different brands of toothpaste at various test dilutions

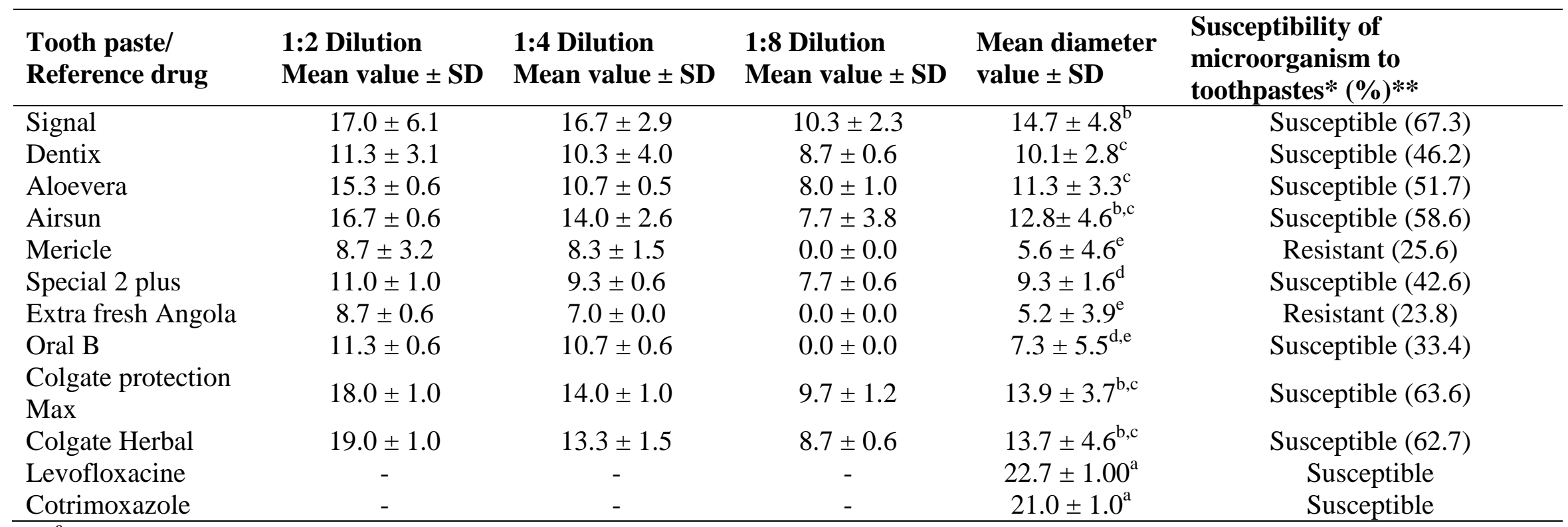

${ }^{\mathrm{a}}$ Values with the same superscript are not significantly different; Student Newman Keuls at $p<0.05$.

*Mean diameter $>7 \mathrm{~mm}$ was considered susceptible and $<7 \mathrm{~mm}$ as resistant.

***mean zone diameter produced by the toothpaste X100/ mean zone diameter produced by the reference substances. 
Table.3 E.coli susceptibility to different brands of toothpaste at various test dilutions

\begin{tabular}{|c|c|c|c|c|c|}
\hline $\begin{array}{l}\text { Toothpaste/ } \\
\text { Reference drug }\end{array}$ & $\begin{array}{c}\text { 1:2 dilution } \\
\text { (Mean value } \pm \\
\text { SD) }\end{array}$ & $\begin{array}{c}\text { 1:4 dilution } \\
\text { (Mean value } \pm \\
\text { SD) }\end{array}$ & $\begin{array}{c}\text { 1:8 dilution } \\
\text { (Mean value } \pm \\
\text { SD) }\end{array}$ & $\begin{array}{l}\text { Mean diameter } \\
(\text { Value } \pm \text { SD })\end{array}$ & $\begin{array}{c}\text { Susceptibility of } \\
\text { microorganism to } \\
\text { toothpastes } *(\%) * *\end{array}$ \\
\hline Signal & $19.0 \pm 1.0$ & $14.0 \pm 1.0$ & $8.0 \pm 1.0$ & $13.7 \pm 4.8^{\mathrm{e}}$ & Susceptible (62.3) \\
\hline Dentix & $12.7 \pm 0.6$ & $10.33 \pm 0.6$ & $6.0 \pm 1.0$ & $9.7 \pm 3.0^{f}$ & Susceptible (44.1) \\
\hline Aloevera & $23.3 \pm 1.5$ & $19.0 \pm 1.0$ & $10.0 \pm 1.0$ & $17.4 \pm 5.9^{c}$ & Susceptible (79.1) \\
\hline Airsun & $12.7 \pm 0.6$ & $9.0 \pm 1.0$ & $0.0 \pm 0.0$ & $7.2 \pm 5.6^{\mathrm{g}}$ & Susceptible (32.7) \\
\hline Mericle & $12.6 \pm 0.6$ & $7.7 \pm 0.6$ & $0.0 \pm 0.0$ & $6.7 \pm 5.5^{\mathrm{g}}$ & Resistant (30.5) \\
\hline Special 2 plus & $12.6 \pm 0.6$ & $8.3 \pm 0.6$ & $0.0 \pm 0.0$ & $7.0 \pm 5.6^{\mathrm{g}}$ & Susceptible (31.8) \\
\hline Extra fresh Angola & $12.6 \pm 0.6$ & $10.7 \pm 0.6$ & $7.0 \pm 1.0$ & $10.1 \pm 2.6^{\mathrm{f}}$ & Susceptible (45.9) \\
\hline Oral B & $11.7 \pm 1.2$ & $8.3 \pm 1.2$ & $0.0 \pm 0.0$ & $6.7 \pm 5.3^{\mathrm{g}}$ & Resistant (30.4) \\
\hline $\begin{array}{l}\text { Colgate protection } \\
\text { Max }\end{array}$ & $20.0 \pm 1.0$ & $15.0 \pm 1.0$ & $8.0 \pm 1.0$ & $14.3 \pm 5.3^{\mathrm{e}}$ & Susceptible (65) \\
\hline Colgate Herbal & $21.7 \pm 0.6$ & $17.7 \pm 0.6$ & $10.0 \pm 1.0$ & $16.4 \pm 5.2^{\mathrm{d}}$ & Susceptible (74.5) \\
\hline Levofloxacine & - & - & - & $25.0 \pm 0.0^{b}$ & Susceptible \\
\hline Cotrimoxazole & - & - & - & $19.0 \pm 0.0^{\mathrm{a}}$ & Susceptible \\
\hline
\end{tabular}

${ }^{a}$ Values with the same superscript are not significantly different; Student Newman Keuls at $p<0.05$.

* Mean diameter $>7 \mathrm{~mm}$ was considered susceptible and $<7 \mathrm{~mm}$ as resistant.

**mean zone diameter produced by the toothpaste X100/ mean zone diameter produced by the reference substances. 
Table.4 S. aureus susceptibility to different brands of toothpaste at various test dilutions

\begin{tabular}{|c|c|c|c|c|c|}
\hline $\begin{array}{l}\text { Toothpaste/ } \\
\text { Reference drug }\end{array}$ & $\begin{array}{c}\text { 1:2 Dilution } \\
\text { Mean value } \pm \mathrm{SD}\end{array}$ & $\begin{array}{c}\text { 1:4 Dilution } \\
\text { Mean value } \pm \text { SD }\end{array}$ & $\begin{array}{c}\text { 1:8 Dilution } \\
\text { Mean value } \pm \mathrm{SD}\end{array}$ & $\begin{array}{l}\text { Mean diameter } \\
\text { value } \pm \text { SD }\end{array}$ & $\begin{array}{c}\text { Susceptibility of } \\
\text { microorganism to } \\
\text { toothpastes } *(\%) * *\end{array}$ \\
\hline Signal & $9.7 \pm 0.6$ & $7.3 \pm 0.6$ & $0.0 \pm 0.0$ & $5.7 \pm 4.3^{\mathrm{e}}$ & Resistant (27.5) \\
\hline Aloevera & $12.3 \pm 0.6$ & $8.3 \pm 0.6$ & $4.6 \pm 4.0$ & $8.4 \pm 3.9^{\mathrm{d}}$ & Susceptible (40.6) \\
\hline Airsun & $10.0 \pm 0.0$ & $7.6 \pm 0.6$ & $0.0 \pm 0.0$ & $5.8 \pm 4.5^{\mathrm{e}}$ & Resistant (28.0) \\
\hline Mericle & $8.3 \pm 0.6$ & $6.7 \pm 0.6$ & $0.0 \pm 0.0$ & $5.0 \pm 3.8^{\mathrm{e}}$ & Resistant (24.2) \\
\hline Oral B & $12.3 \pm 1.2$ & $8.7 \pm 1.2$ & $6.3 \pm 0.6$ & $9.1 \pm 2.7^{\mathrm{c}}$ & Susceptible (43.9) \\
\hline $\begin{array}{l}\text { Colgate protection } \\
\text { Max }\end{array}$ & $15.0 \pm 0.0$ & $10.0 \pm 2.6$ & $7.7 \pm 0.6$ & $10.9 \pm 3.5^{\mathrm{c}}$ & Susceptible (52.6) \\
\hline Colgate Herbal & $13.7 \pm 1.2$ & $9.7 \pm 0.6$ & $7.3 \pm 0.6$ & $10.2 \pm 2.8^{\mathrm{c}}$ & Susceptible (49.3) \\
\hline Levofloxacine & - & - & - & $21.7 \pm 1.5^{\mathrm{a}}$ & Susceptible \\
\hline Cotrimoxazole & - & - & - & $19.7 \pm 0.6^{\mathrm{b}}$ & Susceptible \\
\hline
\end{tabular}

${ }^{\mathrm{a}}$ Values with the same superscript are not significantly different; Student Newman Keuls at $p<0.05$.

*Mean diameter $>7 \mathrm{~mm}$ was considered susceptible and $<7 \mathrm{~mm}$ as resistant.

**mean zone diameter produced by the toothpaste X100/ mean zone diameter produced by the reference substances. 
Table.5 C. albicans susceptibility to different brands of toothpaste at various test dilutions

\begin{tabular}{|c|c|c|c|c|c|}
\hline $\begin{array}{l}\text { Toothpaste/ } \\
\text { Reference drug }\end{array}$ & $\begin{array}{c}\text { 1:2 Dilution } \\
\text { Mean value } \pm \text { SD }\end{array}$ & $\begin{array}{c}\text { 1:4 Dilution } \\
\text { Mean value } \pm \text { SD }\end{array}$ & $\begin{array}{c}\text { 1:8 Dilution } \\
\text { Mean value } \pm S D\end{array}$ & $\begin{array}{c}\text { Mean diameter } \\
\text { value } \pm \text { SD }\end{array}$ & $\begin{array}{c}\text { Susceptibility of } \\
\text { microorganism to } \\
\text { toothpastes } *(\%) * *\end{array}$ \\
\hline Signal & $21.7 \pm 0.6$ & $17.0 \pm 2.6$ & $11.0 \pm 2.6$ & $16.55 \pm 5.0^{\mathrm{d}}$ & Susceptible (73.6) \\
\hline Dentix & $9.3 \pm 1.2$ & $8.0 \pm 1.0$ & $0.0 \pm 0.0$ & $5.8 \pm 4.4^{\mathrm{h}}$ & Resistant (25.8) \\
\hline Aloevera & $16.7 \pm 0.6$ & $13.0 \pm 2.6$ & $9.3 \pm 0.6$ & $13.0 \pm 3.4^{\mathrm{e}}$ & Susceptible (57.8) \\
\hline Airsun & $12.0 \pm 1.0$ & $8.7 \pm 0.6$ & $0.0 \pm 0.0$ & $6.9 \pm 5.4^{\mathrm{g}}$ & Resistant (30.7) \\
\hline Mericle & $0.0 \pm 0.0$ & $0.0 \pm 0.0$ & $0.0 \pm 0.0$ & $0.0 \pm 0.0^{\mathrm{i}}$ & Resistant (0) \\
\hline Special 2 plus & $8.7 \pm 0.6$ & $6.3 \pm 0.6$ & $0.0 \pm 0.0$ & $5.0 \pm 3.9^{\mathrm{h}}$ & Resistant (22.2) \\
\hline Extra fresh Angola & $14.3 \pm 1.2$ & $10.7 \pm 0.6$ & $0.0 \pm 0.0$ & $8.3 \pm 6.4^{\mathrm{g}}$ & Susceptible (36.8) \\
\hline Oral B & $8.3 \pm 0.6$ & $7.0 \pm 0.0$ & $0.0 \pm 0.0$ & $5.1 \pm 3.8^{\mathrm{h}}$ & Resistant (22.7) \\
\hline $\begin{array}{l}\text { Colgate protection } \\
\text { Max }\end{array}$ & $13.7 \pm 1.2$ & $11.0 \pm 1.0$ & $8.7 \pm 0.6$ & $11.1 \pm 2.3^{\mathrm{f}}$ & Susceptible (49.3) \\
\hline Colgate Herbal & $22.7 \pm 0.6$ & $20.0 \pm 1.7$ & $16.3 \pm 5.7$ & $19.7 \pm 4.1^{\mathrm{c}}$ & Susceptible (82.7) \\
\hline Ketoconazole & - & - & - & $23.3 \pm 1.5^{\mathrm{a}}$ & Susceptible \\
\hline Miconazole & - & - & - & $21.7 \pm 1.5^{\mathrm{b}}$ & Susceptible \\
\hline
\end{tabular}

${ }^{a}$ Values with the same superscript are not significantly different; Student Newman Keuls at $p<0.05$.

* Mean diameter $>7 \mathrm{~mm}$ was considered susceptible and $<7 \mathrm{~mm}$ as resistant.

**mean zone diameter produced by the toothpaste X100/ mean zone diameter produced by the reference substances. 
Competing interests: The authors declare that they have no competing interests.

\section{Authors' contributions}

GNT conceived the study, designed the method, monitored the experimental and laboratory work, analyzed data, drafted and finalized the manuscript for publication.

NGE did the experimental and laboratory work, collected and transported data and other materials.

ART assisted in the experimental and laboratory work and checked the keyed data prior to analysis. All authors read and approved the final manuscript.

\section{Acknowledgements}

All authors thank the laboratory staff of the Microbiology/ Bacteriology Laboratory of the Yaounde University Hospital Teaching Center for their technical assistance.

\section{References}

Addy, M., Moran, J. 2008. Chemical supragingival plaque control In: Clinical periodontology and implant dentistry (Eds.) J. Lindhe, N.P. Lang, and T. Karring. Oxford: Blackwell Munkgaard. Pp. 734-83.

Agbelusi, G.A., Odukoyo, O.A., Olegbeye, A.F. 2007. Invitro screening of chewing stick extracts and ssap on oral pathogens: Immune compromised infections. Biotechnology jnl., 76(1) : 97-100.

Alsaimary, I. 2008. Efficacy of some antibacterial agents against Strep. mutans associated with tooth decay. The internet J. Microbiology, 7(2): 1-5.

Andiara, D.R., Danielly, C.A., Raquel, A.B., Alexandra, M.Q., Paulo, N.F. 2014. Antimicrobial Activity of Toothpastes Containing Natural Extracts, Chlorhexidine or Triclosan. Brazilian
Dental Journal, 25(3): 186-190.

Aneja, K.R. 2003. Experiments in microbiology plant pathology and biotechnology. 4nd ed, New Age Int. Publishers, New Delhi. $608 \mathrm{p}$.

Cappuccino, J.G., Sherman, N. 1995. Microbiology lab manual. BenjaminCummings Publishing Company, USA. p477.

Chattopadhyay, D., Maiti, K., Kundu, A.P., Chakraborty, M.S., Bhadra, R., Mandal, S.C., Mandal, A.B. 2001. Antimicrobial activity of Astonia macrophylla: a folklore of Bay Islands. $J$ Ethnopharmacol, 77:49-55.

Davies, R., Scully, C., Preston, A.J. 2010. Dentifrices-an update. Med Oral Patol Oral Cir Bucal., 15: 976-982.

Davies, R.M., Ellwood, R.P., Davies, G.M. 2004. The effectiveness of toothpaste containing

triclosan and polyvinyl-methyl ether maleic acid copolymer in improving plaque control and gingival health: a systematic review. J. Clin. Periodontol. 31(12): 1029-33.

Diane, T., Bonnie, B., Patty, W., Lynn, S., Susan, V., Evie, J. 2006. Oral rinsing. Canadian J. Dental Hygiene, 40(4): 168222.

Didry, N., Dubreuil, L., Pinkas, M. 1994. Activity of thymol, carvacrol, cinnamaldehyde and eugenol on oral bacteria. Pharm Acta Helv., 69: 25-28.

Dinesh, M.D., M.S. Uma, S. Meenatchisundaram, V.M. Anjali, P.S. Athira and Asitha Carmel. 2016. Streptococcal Dental Caries - A Short Review. Int.J.Curr.Res.Aca.Rev. 4(1): 160-170.

Farogh, G., Monika, R., Mohini, S.R., Manisha, S., Neha, S., Anushree, V., Abhimanyu, K. 2014. In Vitro Study to Investigate the Antimicrobial Efficacy of Different Toothpastes and Mouth Rinses. RJPBCS., 5(2): 245- 257.

Fejerskov, O., Kidd, E. 2003. Dental caries: the disease and its clinical management. $1 \mathrm{st}$ ed. London: WileyBlackwell;;. 
Teke, G.N., Paul, K.L., Hippolyte, K.W., Kuiate J.R., Vilarem, G., Giacinti G., Haruhisa, K., Yoshiteru, O. 2011. Antimicrobial and antioxidant properties of methanol extract, fractions and compounds from the stem bark of Entada abyssinica Stend ex A. Satabie. BMC Complementary and Alternative Medicine, 11:57.

Teke, G.N., Kemadjou, N.E., Kuiate, J.R. 2013. Chemical composition, antimicrobial properties and toxicity evaluation of the essential oil of Cupressus lusitanica Mill. leaves from Cameroon. BMC Complementary and Alternative Medicine, 13:130.

Gunsolley, J.C. 2006. A meta-analysis of sixmonth studies of antiplaque and antigingivitis

agents. J Am Dent Assoc., 137(12): 164957.

How, K.Y., Keang, P.S., Kok, G.C. 2016. Porphyromonas gingivalis: An Overview of Periodontopathic Pathogen below the Gum Line. Front Microbiol., 7: 53.

Ihsan, E. 2008. Efficacy of some antibacterial agents against Streptococcus mutans associated with tooth decay. The internet J. Microbiology, 7(2): 1-5.

Inetianbor, J.E., Ehiowemwenguan, G., Yakubu, J.M., Ogodo, A.C., 2014. INVITRO ANTIBACTERIAL ACTIVITY OF COMMONLY USED TOOTHPASTES IN NIGERIA AGAINST DENTAL PATHOGENS. $J$ Adv Sci Res, 5(2): 40-45.

Jenkins S, Addy M, Newcombe R. Triclosan and sodium lauryl sulphate mouthwashes (I). Effects on salivary bacterial counts. J Clin Periodontol. 1991;

18(2):140-44.

Jenner, F., Jaleel, V.A., Kulshrestha, R., Maheswar, G., Rao, P.K., Kranthi, J. 2013. Evaluating the antimicrobial activity of commercially available toothpastes on microorganisms associated with diabetes mellitus. J. contemporary dental practice, 14(5): 924-929.

Jeronimo, M., Vinicius, P., Sandra, S. 2013.
How to deal with morning bad breath. $J$. Indian society of Periodontology, 17(6): 757-761.

Kallahalli, M., Sanjay, V., Govinduraju, P., Darshana, B., Bhadravathi, V., Antharasanahalli, S. 2015. Antimicrobial efficacy of commercially available toothpastes. J. young Pharmacists, 7(3): 187-193.

Kjaerheim, V., Waaler, S.M. 1994. Experiments with triclosan-containing mouthrinses: dose response--and an attempt to locate the receptor site(s) of triclosan in the mouth. Adv Dent Res., 8(2): 302-06.

Krzysciak, W., Jurczuk, A., Koscielniak, B.B., Skalniak. 2014. The virulence of Strep mutans and the ability to form biofilms. Eur Clin Microbiol Infect Dis., 22(4): 499-515.

Loesche, W.J. 1986. Role of Streptococcus mutans in human dental decay. Microbio Rev., 50: 353-380.

Lowy, F.D. 1998. N Engl J Med., 339(8): 520532.

Piochi, B.J., Zelante, F. 1974. Rev Fac Odontol Sao Paulo, 13(1): 91 -97.

Manupati, P. 2011. Antimicrobial Efficacy of mouth rinses. Dental Res Journal, 8(2): 85- 94.

Mogammad, T.P., Charlene, W.J.A., Lawrence, X.G.S., Johan, M., Abdul, M. 2011. An in-vitro analysis of the antimicrobial efficacy of herbal toothpastes on selected primary plaque colonizers. Int. J. Clinical Dental Science, 2(3): 28-32.

Netuschil, L., Brexc, M., Heumann, C., Hoffman, T. 2005. Clinically controlled 6-month study of the influence of toothpastes with anti-inflammatory ingredients on plaque and gingivitis. Quintessenz, 56:1277-86.

Nwakanma, C., Ejim, C., Unachukwu. 2014. The effects of selected toothpaste on the microbial flora of the mouth of GOU student. Int. J. Current Microbiology and Applied Sciences, 3(9): 785-792.

Nwankwo, I., Ihesiulo, S. 2014. Comperative analysis of the Antibacterial potentials of some Brands of toothpaste commonly 
used in Umuahia Abia State. IOSR $J$. Pharmacy and Biological Sciences (IOSR-JPBS), 9(3): 50-54.

Okpalugo, J., Ibrahim, K., Inyang, U. 2009. Toothpaste formulation efficacy in reducing oral flora. Tropical $J$. Pharmaceutical Research, 8 (1): 71 -77.

Oranusi, V., Akhigbe, E. 2013. Antimicrobial activity and Micro-flora quality evaluation of commonly used toothpastes. Int. J. Biology, Pharmacy and Allied Sciences, 2(7): 1388-1399.

Otoikhian, C.S.O., Okoror, L.O. 2012. Resistance of oral bacterial species to varied toothpastes effects. Int. J. Engg. Res. \& Sci. \& Tech., 1( 1).

Ozaki, F., Claudio, M.P., Ana, Vitória I., Pessotti, W., Saraiva, L., Nívea, M.F., Ferrari, G., Cabral, V.N. 2006. Efficacy of herbal toothpaste on patients with established gingivitis- a randomized control trial. Braz Oral Res., 20(2): 172-177.

Oztan, M., Kiyan, M., Gerceker, D. 2006. Invitro antimicrobial effect of gutta percha points containing root canal medications against yeast and Enterococcus faecalis. Oral Surg, oral med oral pthol oral Radio Endod., 1002: 410-6.

Prasanth, M. 2011. Antimicrobial Effiacy of
Different Toothpastes and Mouthrinses: An

In Vitro Study. Dent Res J., 8(2): 85-94.

Robert, C., Caren, M., Annerose, B., Robert, L., Kenneth, H., Mark, E. 2011. Evidence of the Efficacy of an Alcohol-free mouth wash containing cetyl pyridinium chloride. J. Clinical Dentistry, 22(6): 179204.

Shetty, N. 2007. Infectious Disease. 1 st Edition. United Kingdom. John Willey and sons;.

Socransky, S.S., Haffajee, A.D. 2005. Periodontal microbial ecology. Periodontol 2000, 38: 135-187.

Violet, I., Joseph, J., Prem, K. 2012. Evaluation of the Antimicrobial Activity of Dentifrices on Human Oral Bacteria. The J. Clinical Dentistry, 21(4): 96-100.

Williams, M., Ummins, D.C. 2005. The technology behind Colgate Total toothpastes. Oral Diseases,11(suppl 1): 98-121.

Willliams, M.I and Cummins, D.M. 2003. "The Technology behind close-up total advanced fresh" comprehensive continue education on dentals. British J. Dental Surgery, 24(5): 4-9.

Yoo, S.Y., Park, S.J., Jeing, D.K., Kim, K.W., et al. 2007. J. Microbiol., 45(3): 246-255.

\section{How to cite this article:}

Gerald Ngo Teke, Ngolle Godwill Enongene and Akah Roland Tiagha. 2017. In vitro Antimicrobial Activity of Some Commercial Toothpastes. Int.J.Curr.Microbiol.App.Sci. 6(1): 433-446. doi: http://dx.doi.org/10.20546/ijcmas.2017.601.052 